\title{
Impact of COVID-19 on Acute Viral Bronchiolitis Hospitalization Among Infants in North India: Authors' Reply
}

\author{
Suresh Kumar Angurana ${ }^{1}\left[\right.$ [ Lalit Takia $^{1} \cdot$ Puspraj Awasthi $^{1}$
}

Received: 14 October 2021 / Accepted: 12 November 2021/Published online: 14 January 2022

(c) Dr. K C Chaudhuri Foundation 2021

To the Editor: We are happy to respond to the comments by Sookaromdee and Wiwanitkit [1] in response to our article "Impact of COVID-19 on Acute Viral Bronchiolitis Hospitalization Among Infants in North India" [2].

The possible reasons for change in the incidence, hospitalization, and severity of acute viral bronchiolitis (AVB) during the coronavirus disease 2019 (COVID-19) pandemic are infection prevention and control measures like widespread use of face masks, hand hygiene, and social isolation and distancing; closure of schools and daycare centers; restricted transport facilities; and limited accessibility to hospitals. Similar reasons have been proposed by authors from other parts of the world [3, 4].

We commonly see the cases of AVB during the months of October to February (postmonsoon and winter season) (seasonal variation) $[2,5]$. The pattern of AVB epidemiology might change on a yearly basis. However, the change in the number of admissions due to AVB in Pediatric emergency during the prepandemic and pandemic period was drastic [173 out of 3770 admissions (4.6\%) vs. 8 of $1589(0.5 \%)$ admissions, respectively, $p=0.001]$.

Grimaud et al. [6] reported 2 infants ( $<3$ mo old) who presented with fever and neurological symptoms with history of contact with COVID-19 case in family. These infants developed features suggestive of AVB after a delay of 2-8 d. Their nasopharyngeal swab for SARS-CoV-2 RT-PCR was positive but negative for RSV and influenza virus. This report highlighted the fact that the SARS-CoV-2 infection may cause AVB [6].

There is need to monitor the epidemiology of respiratory diseases after COVID-19 pandemic. The impact of
COVID-19 on occurrence and pattern of AVB; long-term effects of COVID-19 on the lungs (structure and function) of children; and impact of SARS-CoV-2 infection (a/symptomatic) on predisposition to recurrent wheezing or asthma need to be determined [6].

\section{Declarations}

Conflict of Interest None.

\section{References}

1. Sookaromdee P, Wiwanitkit V. Impact of COVID-19 on Acute viral bronchiolitis hospitalization among infants in North India: correspondence. Indian J Pediatr. 2021.https://doi.org/10.1007/ s12098-021-04033-8

2. Takia L, Awasthi P, Angurana SK. Impact of COVID-19 on acute viral bronchiolitis hospitalization among infants in North India. Indian J Pediatr. 2021;88:1154.

3. Friedrich F, Ongaratto R, Scotta MC, et al. Early impact of social distancing in response to COVID-19 on hospitalizations for acute bronchiolitis in infants in Brazil. Clin Infect Dis. 2021;15:2071-5.

4. Van Brusselen D, De Troeyer K, Ter Haar E, et al. Bronchiolitis in COVID-19 times: A nearly absent disease? Eur J Pediatr. 2021;180:1969-73.

5. Angurana SK, Williams V, Takia L. Acute viral bronchiolitis: A narrative review. J Pediatr Intensive Care. 2020. https://doi.org/ 10.1055/s-0040-1715852.

6. Grimaud E, Challiol M, Guilbaud C, et al. Delayed acute bronchiolitis in infants hospitalized for COVID-19. Pediatr Pulmonol. 2020;55:2211-2.

Publisher's Note Springer Nature remains neutral with regard to jurisdictional claims in published maps and institutional affiliations.

Suresh Kumar Angurana

sureshangurana@gmail.com

1 Division of Pediatric Critical Care, Department of Pediatrics, Advanced Pediatric Center, Postgraduate Institute of Medical Education and Research (PGIMER), Chandigarh 160012, India 